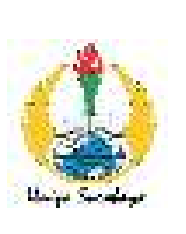

Volume 03 Nomor 01, Juni 2021 Page 22-25

\author{
Incrementapedia: Jurnal Pendidikan Anak Usia Dini \\ Program Studi PG-PAUD Fakultas Pedagogi dan Psikologi \\ Universitas PGRI Adi Buana Surabaya \\ http://jurnal.unipasby.ac.id/index.php/incrementapedia \\ e-ISSN: 2686-3146
}

\title{
PENGARUH PERMAINAN PUZZLE TERHADAP KEMAMPUAN DAYA INGAT ANAK KELOMPOK B
}

\author{
Aisyah \\ (Progran Studi Pendidikan Guru Pendidikan Anak Usia Dini, Fakultas Pedagogi dan Psikologi \\ Universitas Adi Buana Surabaya) \\ aisyah@unipasby.ac.id
}

\begin{abstract}
Puzzle is a game that is played with the aim of arranging images, images are randomized beforehand. So people who play it try to arrange it in the frame by connecting pieces or pieces of small images so that they become whole images. Puzzle games given to young children are expected to benefit the children's memory abilities. Pejajaran Kindergarten which in this case the learning model is still classical and the teacher center is still very minimal in providing constructive educational games for early childhood. This is a problem for early childhood, by providing puzzle games, it is hoped that children can improve their memory. According to Jamil (2008:81) This puzzle game tests the speed and accuracy of a child's reaction to a hint given to him. This study uses a preexperimental research design with the type of One-Group Pre-Test Post-Test. The subjects in this study were group $B$ TK Pejajaran with a total of 25 children. With observation and documentation data collection techniques. While the analysis using SPSS V.20. The results of research with the test Sig $(0,000)<0,005$ means there is an influence between the puzzle game with the child's memory ability. Puzzle games in addition to memory skills can also train children to solve problems, develop eye and hand coordination, develop cognitive and fine motor skills.
\end{abstract}

Keywords : Benefits of Puzzles, children's memory

\section{PENDAHULUAN}

Pendidikan anak usia dini (PAUD) adalah jenjang pendidikan sebelum jenjang pendidikan yang merupakan suatu upaya pembinaan yang ditujukan bagi anak sejak lahir sampai dengan usia enam tahun yang dilakukan melalui pemberian rangsangan pendidikan untukmembantu pertumbuhan dan perkembangan jasmani dan rohani agar anak memiliki kesiapan dalam memasuki pendidikan lebih lanjut, yang diselenggarakan pada jalur formal, nonformal, dan informal.

TK merupakan salah satu jenis lembaga atau instansi pendidikan formal. Usia 5-6 tahun merupakan usia yang sangat menentukan dalam pembentukan karakter dan kepribadian. Permainan puzzle seperti yang kita tahu merupakan sebuah permainan menyusun potongan - potongan gambar yang nantinya akan menjadi sebuah gambar yang utuh. Dikatakan juga kalau permainan ini mampu menambah kecerdasan bagi orang yang memainkannya. Tentunya juga sangat bermanfaat terutama bagi perkembangan anak. Menurut penelitian dari National Science Foundation yang dilakukan oleh Susan C. Levine pada 2012, anak usia 2-4 tahun yang rutin bermain puzzle memiliki keterampilan visual spasial yang lebih baik dibandingkan yang tidak. Hal ini dikarenakan kemampuan mengenal dan memahami bentuk, ukuran, warna, dan ruang yang lebih terasah melalui puzzle.

latar belakang dari penelitian ini, dimana lembaga ini masih menggunakan metode pembelajaran yang klasikal yang berpusat pada guru.Sehingga membuat anak menjadi jenuh dan bosan karena pembelajaran yang kurang menarik. Hal ini yang membuat penulis ingin memberikan APE seperti puzzle untuk dapat meningkatjan kemampuan daya ingat anak kelompok B, karena permainan puzzle untuk melatih daya ingat anak, dimana anak-anak disana kurang diberikanpermainan yang dapat melatih daya ingat, kreatifitas yang membangun karakter anak tersebut.. Adanya permainan puzzle yang akan diberikan diharapkan dapat meingkatkan daya ingat anak.

Bermain menurut Smith and Pellegrini (dalam Musfiroh, 2015:1.5) merupakan kegiatan yang dilakukan untuk kepentingan diri sendiri, dilakukan dengan cara menyenangkan tidak diorientasikan pada hasil akhir, fleksibel, aktif dan positif, sedangkan Menurut piaget (dalam Anies \& Djoko, 2017:86) mengatakan bahwa bermain adalah sesuatu kegiatan yang dilakukan secara berulang- 
ulang dan akan menimbulkan kesenangan, kepuasan bagi diri sendiri.

Menurut Ahmadi \& Sholeh (2005:92) daya ingatan anak akan bersifat tetap jika anak telah mencapai umur \pm 4 tahun. Selanjutnya daya ingatan anak akan mencapai intensitas terbesar atau terbaik dan kuat, jika anak berumur antara $\pm 8-12$ tahun, pada saat itu daya menghafal atau daya memorisasi (upaya memasukkan pengetahuan dalam tingkatan seseorang) dapat memuat sejumlah materi hafalan sebanyak mungkin. Sebelum umur setengah tahun $(0 ; 6)$ anak pada umumnya belum mengenal benda sekitarnya secara hakiki, anak saat itu baru mengenal keadaan atau situasinya saja., ia mengenal keadaan itu. Tetapi jika sendok ditaruh/diletakkan di atas meja, maka anak sudah secara pelan-pelan anak mulai mengenal lingkungannnya.

Dari uraian diatas dengan beberapa kesimpulan tentang memory/daya ingat, maka penulis menyimpulkan bahwa ingatan / daya ingat merupakan penyimpanan atau penerimaan sepanjang waktu untuk menyimpan informasi dengan menerima, merangsang, mengolah kembali sesuai dengan daya tangkap seseorang.

Selama masa awal anak-anak, memory jangka pendek mereka telah berkembang dengan baik. Tetapi setelah anak berusia 7 tahun tidak terlihat peningkatan yang berarti. Cara mereka memproses informasi menunjukkan keterbatasan- keterbatasan dibandingkan dengan orang dewasa. Berbeda dengan memori jangka panjang, terlihat peningkatan seiring dengan penambahan usia selamamasa petengahan dan akhir anak-anak. hal ini karenamemori jangka panjang sangat tergantung pada kegiatankegiatan belajar individu ketika mempelajari dan mengingat informasi. peneliti membatasi penelitian pada Pengaruh

: Permainan puzzle terhadap kemampuan daya ingat anak kelompok B. Sedangkan rumusan permasalahan dari penelitian ini adalah : Apakah ada pengaruh permainan puzzle terhadap kemampuan daya ingat pada anak kelompok B ?

Dengan tujuan ingin mengetahui apakah ada pengaruh permainan puzzle terhadap kemampuan daya ingat anak kelompok B.

\section{METODE PENELITIAN}

Metode penelitian kuantitatif merupakan metode penelitian yang dimaksudkan untuk menjelaskan fenomena dengan menggunakan data- data numerik, kemudian dianalisis yang umumnya menggunakan statistik, menurut Daniel Muijs (dalam Suharsaputra, 2014:49).

Dalam penelitian kuantitatif ini dibutuhkan desain penelitian yang berfungsi sebagai rambu- rambu penelitian agar tidak menyimpang dari tujuan penelitian tersebut. Sehingga tujuan untuk mengetahui ada pengaruh permainan puzzle terhadap kemampuan daya ingat kelompok $\mathrm{B}$ dapat dicapai dengan hasil yang maksimal dan akurat sesuai dengan rumus rumus yang ada.

Penelitian ini termasuk penelitian kuantitatif eksperimen yaitu suatu penelitan atau riset dimana satu atau lebih variabel indpenden secara sengajadimanipulasi oleh peneliti dengan menggunakan perlakuan, layanan, interverensi sosial tertentu. Pengaruh dari manipulasi terhadap dependent variable kemudian diukur setelah dilakukan perlakuan.

Desain dalam penelitian ini menggunakan pre eksperimen designs dengan bentuk One Group Pretes-Posttes Design. Desain ini menyatakan bahwa di dalam penelitiannya terdapat pre test sebelum diberi perlakuan. Dengan demikian hasilperlakuan dapat diketahui lebih akurat karena dapat membandingkan dengan keadaan sebelum diberi perlakuan. Rancangan perlakuan dalam penelitian ini dapat digambarkan sebagai berikut:

\section{$0_{1} \times 0_{2}$}

Populasi dari penelitian ini adalah peserta didik kelompok B sebanyak 43 peserta didik. Menurut Suharsaputra (2014:117) pengambilan sampel berstrata merupakan teknik pengambilan sampel dimana populasi dikelompokkan dalam strata tertentu, kemudian diambil sampel secara random dengan proporsi yang seimbang sesuai denganposisinya dalam populasi.

Sampel dalam penelitian kuantitatif merupakan subjek penelitian yang di anggap mewakili populasi dan biasanya disebut juga dengan responden penelitian. Adapun pengambilan sampel dalam penelitian ini dengan stratified sampling yang berjumlah 25 anak dari jumlah 43 peserta didik kelompok B.

Dalam penelitian kuantitatif, kualitas instrumen penelitian berkenaan dengan validitas dan reabilitas instrumen dan kualitas pengumpulan data berkenan ketepatan cara-cara yang digunakan untuk mengmpulkan data. Oleh karena itu instrumen yang telah teruji validitas dan reabilitasnya, belum tentu dapat menghasilkan data yang valid dan reliabel, apabila instrumen tersebut tidak digunakan secara tepat dalam pengumpulan datanya. Peneliti menentukan pedoman observasi yang digunakan sebelum dan sesudah perlakukan. 
Pedoman observasi digunakan untuk memperoleh data tentangpermainan puzzle terhadap kemampuan daya ingat anak kelompok B yang diterapkan sebelum dan sesudah diberikan perlakuan. Peneliti mengadakan penelitian dengan cara mengumpulkan data secara langsung, melalui pengamatan di lapangan terhadap aktivitas yang akan di lakukan untuk mendapatkan data tertulis yang di anggap relevan. Pada penelitian ini peneliti akan menggunakan pedoman checklist untuk mengetahui keadaan yang terjadi di tempat penelitian. Dokumentasi dalam penelitian ini berupa foto-foto kegiatan permainan puzzle yang disesuaikan dengan RPPH disekolah untuk penilaiankemampuan daya ingat anak selama peneliti melakukan penelitian di kelompok B. Dokumentasi tersebut digunakan untuk mendukung data hasil observasi dan supaya dapat lebih dipercaya.

Teknik analisis data merupakan cara yang dilakukan untuk menganalisis terhadap data dengan tujuan supaya pengelolaan tersebut dapat menjawab rumusan masalah. Apabila sudah terkumpul data yang diperlukan dalam penelitian, untuk memperoleh hasil data diolah terlebih dahulu melalui analisis data. Analisis data dilakukan denganuji t menggunakan aplikasi SPSS versi 22.

\section{HASIL DAN PEMBAHASAN}

Dari hasil penelitian ini penulis akan menguraikan data serta hasil pembahasan mengenai “ Pengaruh Permainan puzzle terhadap kemampuan daya ingat anak kelompok B". Pengumpulan data dan penyajian yaitu pretest dan post-test dipaparkandalam bentuk tabel yang selanjutnya dilakukan mencari hasil uji beda antara pre-test dan post test, kemudian melakukan uji hipotesis dan mencari hasil uji signifikan T-Test (T-hitung) yang dilakukan padakelompok B dengan jumlah 25 anak yang menggunakan metode observasi dan dokumentasi untuk pengumpulan data.

Dalam pelaksanaan pre-test, anak dibiarkanmengerjakan apa yang diberikan oleh peneliti dan melihat sejauh mana pemahaman anak dalam menyelesaikan puzzle tanpa arahan dan bimbingan terlebih dahulu. Sehingga yang terjadi adalah siswa yang berkembang sangat baik dan sesuai harapan tidak ada. Hal ini di karenakan kemampuan daya ingat anak belum lebih baik sehingga belum tercapai secara maksimal.

Pelaksanaan post-test ini sebagaima besar anak dapat mencapai kriteria berkembang angat baik dan berkembang sesuai dengan harapan, hal ini dikarenakan siswa kelompok diberikan perlakuan dahulu setelah pre-test dengan memberikan abjad a$\mathrm{z}$, membandingkan mana yang besar dan kecil, memberikan contoh bagaimana meletakkan puzzle, menyusun huruf sesuai dengan gambar.

Permainan puzzle yang diberikan peneliti sangat disukai anak-anak karena dengan bermain samil belajar dapat membuat anak menjadi tidak jenuh dan lelah. Sedangkan pembelajaran yang didapat siswa kelompok B di TK Pejajaran masih menggunakan metode klasikal dengan berpusat pada guru.

Paired Samples Correlations

\begin{tabular}{|ll|r|r|r|}
\hline & N & Correlation & Sig. \\
\hline $\begin{array}{l}\text { Pair } \\
1\end{array}$ & $\begin{array}{l}\text { pretest \& } \\
\text { posttest }\end{array}$ & 25 &, 714 &, 000 \\
\hline
\end{tabular}

Jika Sig $>0,05$ maka Ho diterimaJika Sig $<\quad 0,05$ maka Ho ditolak Untuk uji 2 sisi, maka nilai : 2 Jadi $95 \%$

Sig $>0,05 / 2$ maka Ho

diterimaSig $<0,05$ maka

Ho ditolak $0,000<0,025$ (Ho

Ditolak)

Dari tabel 4.5 diatas, menunjukkan bahwa hasil penelitan dengan hitung uji t Sig $(0,000)<0,005$ berarti ada pengaruh antara permainan puzzle dengan kemampuan daya ingat anak kelompok B .

Dari hasil data penelitian yang diperoleh peneliti, bahwa ada pengaruh antara permainan puzzle dengan kemampuan daya ingat anak pada kelompok B. pembelajaran pada TK Pejajaran masih kuno dan belum berkembang, tetapi sebenarnya peserta didik sangat berpotensi baik. Oleh sebab itu peneliti melihat kekurangan yang terjadi dimana anak kelompok $\mathrm{B}$ belum memahami dengan benar konsep huruf dan angka sehingga ada sebagian anak yang belum mampu membaca dengan cepat dan ketinggalan dengan teman lainnya.

Kurangnya media pembelajaran yang ada disekolah menjadi penyebab anak menjadi bosan dan kurang bersemangat dalam pembelajaran. Dan membuat daya kreatifitas anak tidak berkembang sesuai harapan. Model pembelajaran klasikal yang berpusat pada guru masih berlaku di lembaga inisehingga apa yang diterima anak hanya dengan apa yang diberikan guru yang membosankan untuk anak usia dini.

Adanya pengaruh terhadap kemampuan daya ingat dengan memberikan permainan 
puzzle ini terlihat ketika anak-anak mampu menyelesaikan dengan tepat dan cepat, menyebutkan nama gambar setelah disusun, menyusun pola dengan benar serta mengenal bentuk pola puzzle yang akan digabungkan. (1) Meningkatkan daya ingat, Permainan puzzle dapat meningkatkan kemampuan daya ingat jangka pendek. Sebab pada permainan puzzle anak menggunakan otak untukmengingat kembali bentuk dan warna gambar puzzle yang sedang disusun. Oleh karena itu, jika sering bermain puzzle, otak akan terlatih dalam mengingat, terutama ingatan jangka pendek ;

(2) meningkatkan kemampuan dalam penyelesaian masalah,Permainan puzzle menuntut pemainnya untuk melakukan trial and error dan dikombinasikan dengan pendekatan sistematis. Hal ini akan mengasah kemampuan otak untuk melakukan problem solving dengan efektif dan kreatif ; (3) Mengasah kemampuan geometri abstraksi ruang, dalam menyelesaikan puzzle anak dituntut untuk menggunakan berbagai kemampuan berpikir, termasuk kemampuan geometri dan abstraksi ruang. Hal ini terutama dapat Anda temui pada permainan puzzle tiga dimensi. alam permainan puzzle anak dilibatkan secara langsung, anak beajar dengan apa yang dilihat, anak melihat dengan jelas menyusun bentuk sesuai dengan pola dan permainan yang edukatif untuk perkembangan anak usia dini. Menurut Fadillah (2018:68) alat permainan edukatif sangatbesar manfaatnya bagi perkembangan anak, seperti fisik-motorik, kognitif, bahasa, imajinasi, kreatifitas, dan sosial emosional. Semakin beragam manfaat alat permainan bagi perkembangan anak, maka semakin besar pula nilai-nilai edukatif di dalamnya.

Dalam suatu permainan untuk anak usia dini yang dilakukan berulang-ulang dan menimbulkan kesenangan serta kepuasan sehingga dapat memberikan kesempatan anak bereksplorasi, mengekpresikan perasaan, berkreatifitas sehingga menimbulkan sistem pembelajaran yang menyenangkan dan dapat diterima dengan anak cukup baik sehingga anak dapat berkembang denganoptimal.

\section{SIMPULAN}

Dengan hasil penelitian dari perhitungan SPSS dengan nilai Sig $(0,000)<0,05$. Permainan puzzle memberikan dampak yang sangat baik terhadap kemampuan daya ingat anak kelompok
B. hal ini dapat dilihat bahwa anak mampu menyelesaikan puzzle dengan cepat dan tepat, mengenal warna dan mengelompokkan bagianbagian dari potongan puzzle dan membentuk menjadi sebuah gambar.

Pada saat proses penelitian berlangsung, anak sangat antusias sekali dengan permainan puzzle yang diberikan peneliti. Mereka sangat senang sekali saat diajak bermain puzzle dan mereka juga mampu menyelesaikan dengan cepat dan tepat serta mampu menyusun pola puzzle yang tidak beraturan dengan tepat. Terlihat disini bahwa peserta didik di TK Pejajaran sangat antusias sekali jika diberikan permainan edukatif yang dapat mengembangkan dan mendukung pembelajaran.

Permainan puzzle selain untuk kemampuan daya ingat ingat juga dapat melatih anak memecahkan masalah, mengembangkan koordinasi mata dan tangan, pengembangan ketrampilan kognitif dan motorik halus.

\section{DAFTAR PUSTAKA}

Ahmadi\&Sholeh. 2005. Psikologi Perkembangan, Jakarta : PT. Rineka Cipta

Anies\&Djoko. 2017. Kompendium Pendidikan Anak Usia Dini. Depok : Prenadamedia Group.

Musfiroh, 2005. Bermain Sambil belajar \& mengasah kecerdasan, Jakarta : DEPDIKNAS.

Suharsaputra U. 2014. Metode Penelitian Kuantitatif, Kualitatif, dan Tindakan. Bandung: PT. Refika Aditama.

Thobroni\&Mumtaz. 2011.

Mendongkrak

Kecerdasan Anak Melalui Bermain dan Permainan. Yogyakarta : Ar-Ruzz Media

Yulianty,R. 2016. Permainan yang meningkatkan kecerdasan anak. Jakarta : Laskar Aksara.

Yusuf, Muri. 2017. Metode Penelitian Kuantitatif, Kualitatif, dan Penelitian Gabungan. Jakarta: KENCANA

Susanto, Ahmad. 2014. Perkembangan Anak Usia Dini Pengantar Dalam Berbagai Aspeknya. Jakarta: KENCANA. Siregar, Syofian. 2015. Metode Penelitian Kuantitatif. Jakarta: Kencana. Sugiono. 2018. Metode Penelitian Pendidikan. Bandung: Alfabeta.

Masitoh, dkk. 2005. Strategi Pembelajaran TK. Jakarta: Universitas Terbuka. Mutiah, Diana. 2015. Psikologi Bermain Anak Usia Dini. Jakarta: Kencana 